\title{
Irony, Contradiction, and Voltaire's Garden: Re-Reading Candide
}

\author{
Sydney Adams \\ Faculty Mentor: Dr. Christoph Irmscher, Department of English, Indiana University Bloomington
}

\begin{abstract}
Literary scholars have long debated the thematic significance of Voltaire's Candide, a 1759 novella that relentlessly satirizes Gottfried Leibniz's philosophy of optimism. In Candide, Voltaire assails his readers with displays of violence so absurd they might inspire anything from laughter to hopelessness. The novella's crude humor is hinged upon an unexpectedly-compassionate acknowledgement of human suffering. Voltaire uses Candide's plotline to attack the human assumption that any force of good will ever offset the evil in a world pervaded by cruelty and selfishness. He provokes questions with no answers in sight. Deriving a theme from the novella only becomes more difficult after reading its conclusion, which leaves readers dissatisfied, desperate for some sort of call to action. We are urged to cultivate our garden but given no advice on what that might entail. We are convinced of Leibnizian optimism's failures but deprived of a more-pragmatic philosophy to replace it with. In this essay, I analyze the ways Voltaire uses humor, irony, and structure in Candide not only to denounce deceitful forms of optimism, but to provoke future thought on the questions he could not answer himself.
\end{abstract}

\section{KEYWORDS: Voltaire, Candide, optimism, irony, humor, social action, realism, pragmatism, sentimentalism, Lisbon, Leibniz}

\section{INTRODUCTION}

$\mathrm{I}_{\mathrm{it}}^{\mathrm{n}}$

order to cope with the inevitable miseries accompanying existence,

it is not uncommon for human beings to rely on the assumption that some pervasive, unconquerable force of goodness will eventually offset all the hardship they have experienced. But in the wake of disaster and violence, hopelessness threatens the legitimacy of this assumption. After the Lisbon earthquake of 1755, writer and philosopher FrançoisMarie Arouet (better known by his pen name, Voltaire) attacked optimistic philosophies that suggested reasonless death and carnage could somehow be "for the best." ${ }^{1}$ Three years after the disaster, Voltaire wrote Candide, a self-proclaimed philosophical tale satirizing philosophy itself. No individual, religion, or society mentioned in Candide is spared from Voltaire's relentless satire and often horrifying plotline, culminating in a novel that is as unsettling as it is comical, as emotionally-wrought as it is flippant. Voltaire uses ludicrous displays of irony to emphasize the human capacity to rationalize the absurd with philosophies that offer no pragmatic value. He complicates this view with the notion that the kind of peace that bores is not necessarily preferable to suffering that stimulates.

From start to finish, Candide's picaresque plot is disconcertinglyand intentionally-contradictive. Speaking for other scholars, Roy S. Wolper evokes the "indecision and conflicting theories concerning structure, style, theme, and characters" that characterize Candide. ${ }^{23}$ Critics have struggled to establish connections between Candide's messages and Voltaire's biography, hoping to reach consensus on what the novel has to say about social action and philosophy. Andrea Speltz writes that Candide is filled with verbal, historical, situational, and structural irony that "serves the anti-systemic thinking of its author," simultaneously affirming and negating philosophical ideas like sentimentalism and egoism. To Speltz, these contradictions are a tool to diagnose "the moral narcissism inherent in sentimentalism" and condemn the human "tendency to linger self-indulgently over beautiful feelings at the expense of active compassion." 3 Michael Wood argues that Voltaire uses Candide to subtly attack the assumptions that "we can totally transcend our selfishness," that "a final accounting of the balance of good and evil...is achievable" and

\footnotetext{
Voltaire, Candide, trans. Roger Pearson (Oxford: Oxford University Press, 1990), 2. 2 Roy S. Wolper. "Candide, Gull in the Garden?” Eighteenth-Century Studies 3, no. 2 (1969), 265.

Andrea Speltz, "War and Sentimentalism: Irony in Voltaire's Candide, Starne's Tristam Shandy, and Lessing's Minna von Barnhelm." Canadian Review of Comparative Literature 44, no. 2 (2017), 286
}

that "philosophies bear...direct relevance to human behavior." ${ }^{4}$ In this essay, I posit that Voltaire's ambiguity and self-contradiction in Candide are deliberately invoked to obscure an easy, uncomplicated discovery of thematic meaning. This prolific, diverse discourse may be exactly what Voltaire hoped for when he wrote Candide. I also argue that the novel's unnervingly ambiguous conclusion is a final twist of irony that is quite intentional on Voltaire's part. In Candide, Voltaire transcends a simple denunciation of optimism, offering a disillusioned perspective on the paradoxical nature of the human condition.

\section{VOLTAIRE'S DISTANCE FROM THE TEXT}

Before attempting an in-depth analysis of Voltaire's intended message in Candide, I must first establish what we know about his relationship with the text. It is easy to assume that Voltaire speaks primarily through protagonist Candide, but this is likely not the case. Even as he introduces Candide, Voltaire's third-person narrator is keen on establishing distance from him. The narrator is not entirely omniscient; in fact, he goes out of his way to suggest that Candide is not someone he knows, but someone he "believe[s]" to be named for his reputed gentle disposition and straightforward mind. ${ }^{5}$ Readers should heed caution in assuming that Voltaire's message aligns with that of any character in the novel-even the unnamed narrator from whose perspective the story is told. I would argue instead that Voltaire speaks through all his characters and the interactions and storyline that fall between them. He speaks through a "man of taste" later in the novel, expressing that the difficulty of literature is "to be a great poet without any of the characters in the piece appearing to be poets themselves." It is no coincidence that Voltaire includes this in the literary connoisseur's commentary; he is slyly, but directly, informing us of his literary intentions. Candide has no singularly wise individual; if it did, it would not be such an effective display of human selfishness and folly. Rather, Voltaire uses the novel in its entirety to convey a satirical depiction of the world around him. Wolper argues this point in his analysis of Candide when he writes that the novel's emphasis on compassion and action reflects "Candide's values, not Candide's." Understanding this distance between Voltaire,

\footnotetext{
Michael Wood, "Notes on Candide," New England Review 26, no. 4 (2005), 19 Voltaire, Candide, 1.

${ }^{6}$ Ibid, 67.

Wolper, "Candide, Gull in the Garden?" 277.
} 
the characters, and the story becomes extremely important when discerning meaning - especially regarding Candide's famous closing scene and the garden Candide urges his companions to cultivate.

\section{THE ROLE OF MULTIPLE PERSPECTIVES}

Though no singular character delivers Candide's theme, each character has a message and a purpose. The most distinctive philosophies are presented first in Pangloss's pedantic optimism, then in Martin's bitter pessimism, and finally in Candide's abandonment of philosophy in favor of action-taking. Pangloss's philosophy is the easiest to identify. His statements function as a clear and intentional satire of Gottfried Wilhelm Leibniz, the German philosopher who coined the phrase "best of all possible worlds" that Pangloss (whose name means "all-tongue") is so fond of. ${ }^{8}$ Voltaire features the inexplicable suffering of the Lisbon disaster in chapter $\mathrm{V}$, and Pangloss, true to form, refuses to relent in his optimism. He goes as far as to remind the victims of the earthquake that all their loss is still "the best there is" and necessary in "the scheme of the best of all possible worlds." ${ }^{9}$ Perhaps the most disturbing implication of statements like this is that no element of Pangloss's character suggests that he says it unkindly; rather, Pangloss deliberately subjects himself and others to delusion. He even convinces Candide that the best of all possible worlds must include Cunegonde's evisceration and rape, since it also included her beauty and love; evil is an "indispensable part of the best of all worlds, a necessary ingredient." ${ }^{10}$ It is this deliberate self-contradiction that Voltaire so vehemently opposes. In his Philosophical Dictionary, he writes that "All is well' means nothing more than that all is controlled by immutable laws. Who does not know that?". ${ }^{11}$ At its best, Leibnizian optimism is to Voltaire an extraneous redundancy, and at its worst, a destructive delusion capable of excusing atrocious displays of immorality and violence.

\section{CANDIDE'S POSITION ON OPTIMISM}

If Pangloss's character represents both Leibnizian optimism and Voltaire's antithesis, one might be inclined to assume that Martin, Candide's most-outspoken pessimist, holds similar views to Voltaire's. But this is an oversimplification of Voltaire's intended message. Martin is a Manichaeist who believes the world's suffering is evidence that God has abandoned it "to some malign being," but Voltaire's work avoids theological justifications for suffering altogether. ${ }^{12}$ Martin's hopelessness might resonate with Voltaire, but Martin does not believe that the trials of hopelessness are worth enduring; Voltaire does. In Voltaire's Politics, historian Peter Gay states that the optimism Voltaire criticizes is at its heart a "halfcomplacent, half-despairing" form of pessimism. ${ }^{13}$ Indeed, Voltaire is careful in his work to distinguish between optimism founded in hope and optimism founded in illusion. He writes in his "Poem on the Lisbon Disaster":

All will be well one day-so runs our hope.

All now is well, is but an idle dream. ${ }^{14}$

Voltaire thus suggests that hope is valuable, though an indiscriminately

\footnotetext{
'Wood, "Notes on Candide," 193; Voltaire, Candide, 2.

${ }^{9}$ Voltaire, Candide, 13-14

${ }^{10}$ Ibid, 9-10.

${ }^{11}$ Voltaire, The Philosophical Dictionary, trans. Theodore Besterman (New York:

Penguin Books, 1972), 71.

2 Voltaire, Candide, 58.

${ }^{13}$ Peter Gay, Voltaire's Politics: The Poet as the Realist (New York: Princeton University

Press, 1959), 21.

${ }^{14}$ Voltaire, "Poem on the Disaster at Lisbon," Toleration and Other Essays, trans.

Jacob McCabe (New York: G. P. Putnam's Sons, 1912), 262.
}

optimistic philosophy is not. Despite her long history of victimhood to atrocious violence, Candide's Old Woman says, "still I loved life." She goes on ironically to criticize this drive to live as "one of our most fatal tendencies" as humans, but she openly clings to existence all the same. ${ }^{15}$ This contradiction resonates with that expressed by Ely in Cormac McCarthy's novel The Road: "Nobody wants to be here, and nobody wants to leave."16 Existence may not be universally pleasant, but we choose to go on with it anyway. While McCarthy's novel suggests that this contradiction is a senseless way of prolonging suffering, Voltaire's seems to admire it as strength.

Candide declares that reality cannot be grounded in the best of all possible worlds, but Voltaire does not seem to believe that we live in the worst of all possible worlds either. Nor does he suggest our world's burdens are not worth bearing. French author Jean Sareil describes the world Voltaire creates in Candide as "simultaneously livable and bad." 17 This is evident in the way that Voltaire's satire absurdly exaggerates the world's capacity for misfortune, but, despite their suffering, his band of characters still try to make a life for themselves at the end of the novel.

\section{THE ROLE OF IRONY}

Throughout Candide, Voltaire also incorporates several instances of verbal irony that produce individual meanings of their own. For example, his narrator's use of the oxymoron "heroic butchery" (boucherie héroïque) suggests that thoughtless acts of violence are inherently incapable of being noble in nature. ${ }^{18}$ Voltaire criticizes moral justifications for violence again later when Candide laments that he is "the best fellow in the world," but he has already killed three men "and two of them priests!"19 In this case, Voltaire's verbal irony not only pokes fun at the absurd measures humans take to justify their own evil, but he also suggests that anyone is capable of violence-and capable of feeling very little remorse for their own destructive choices. Situational irony appears in Candide as well, particularly in instances related to profound, sometimes comical, suffering. This is demonstrated in Voltaire's satirical mention of a eunuch who longs to feel sexual arousal-one of the many characters in the novel whose principal role seems to be to suffer..$^{20}$ Later in the novel, Candide, desperate to find some shred of truth in Pangloss's optimism, makes it his goal to find at least one person content with their life. But inevitably, he fails, having no answer to give Martin when he turns to him "with his usual sang-froid" and asks, "Have I not won the whole bet?"'21

Perhaps the most emotionally jarring display of irony and suffering in the novel arises when Candide meets a slave. The slave plainly notes of his white slaveholders, "I don't know if I made their fortune, but they didn't make mine." ${ }^{22}$ Here Voltaire condemns a non-fictional ironythe way slaves are told that their servitude is an honor, as though they should feel grateful for the way their lives are continually demeaned. Despite the violence Candide witnessed over the course of his odyssey, this moment with the slave shocks him. He cries out in an apostrophe to Pangloss, "I shall finally have to renounce your Optimism." ${ }^{23}$ To deepen the irony of this scene, it is important to note that this is the only direct mention of optimism in the text. It is no mistake that in a book subtitled Loptimisme, Voltaire only writes the word "optimism" once-and when he does, it is to renounce it as madness.

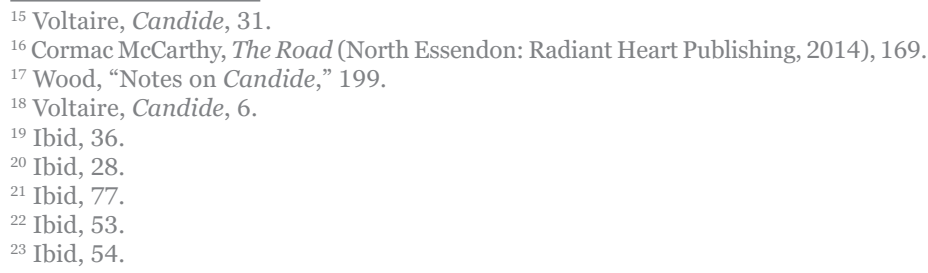


Still, Voltaire's very particular wording in Candide's renunciation of Optimism is worth noting. Candide does not renounce all optimism; he renounces Pangloss's skewed version of it. This clue suggests Voltaire rejects what he perceives as the Leibnizian philosophy of optimism, but perhaps not optimism altogether. As Julian Barnes puts it, Voltaire's issue is with "prepackaged" philosophies. ${ }^{24}$ Regardless, Voltaire never elucidates what his preferred philosophy is. His irony and sarcasm illuminate certain brief messages about violence, misery, and society's role in them, but they offer little insight when it comes to discerning the overarching meaning of the work. And looking to Candide's conclusion only brings more uncertainty.

\section{THE SIGNIFICANCE OF CANDIDE'S FINAL SCENE}

When it seems a fulfilling resolution to Candide's plot could only come from some dramatic display of enlightenment or tragedy, Voltaire offers us neither. After all the disasters, tragedies, and malicious acts that lead to the final scene, Candide and his companions find a peace that, while devoid of outright suffering, is so boring it might be more miserable than violence. Despite the tragedies the Old Woman has endured, she still wonders, "Which is worse... suffering all the misfortunes we've all suffered, or simply being stuck here doing nothing?" 25 In order to, in Martin's words, "make life bearable," Candide suggests that the companions follow the example of an old Turkish man, passing their days tending to the acres of land around them. ${ }^{26}$ Whenever Pangloss attempts to interpret the meaning of their journey to this point, Candide interjects that Pangloss's ideas are fine, "but we must cultivate our garden." ${ }^{27} \mathrm{He}$ repeatedly interrupts philosophy with pragmatism, having no use for discussions of Pangloss's optimism or Martin's pessimism. Philosophical debate will not bring contentment, but work will at least prevent the "three great evils: boredom, vice, and need." 28

It could be argued that the way of life Candide ultimately adopts does not actually achieve anything positive; rather, it is a method of avoiding negatives. Robert Adams in "Candide on Work and Candide as Outsider" points out that Voltaire "does not believe [work] will make you any better, just that it may help you to support evils which are inevitable." ${ }^{29}$ Yet, Voltaire's memorable language-his use of what would become a famous phrase, "cultivate our garden" (il faut cultiver notre jardin)-ascribes significance to the philosophy, implying, as Patrick Henry argues, that "something positive could be accomplished by work." ${ }^{0}$ Perhaps it connects to Candide's commitment to action in the face of disaster. Perhaps it encourages self-improvement in a world of unrelenting cruelty.

Speltz writes that Candide's conclusion is Voltaire's way of alleviating "the tension between war and sentimentalism" by having Candide retreat to a community "beyond national and religious divides." ${ }^{31}$ Some readers may wonder, in a world as miserable as Candide's, is his philosophy ultimately just a "therapy of forgetting?"32 It is important to note that Candide and his companions turn their

\footnotetext{
${ }^{4}$ Julian Barnes, "A Candid View of Candide," The Guardian, last modified July 11 2011, http://www.theguardian.com/books/2011/jul/01/candide-voltaire-rereadingjulian-barnes.

${ }^{25}$ Voltaire, Candide, 96.

${ }^{26}$ Ibid, 99.

${ }^{7}$ Ibid, 100.

${ }^{28}$ Ibid, 98.

${ }^{29}$ Robert Adams, "Candide on Work and Candide as Outsider," Candide, or Optimism: A New Translation, Backgrounds, And Criticism, by Voltaire, trans. Robert Adams (New York: Norton, 1966), 168.

${ }^{30}$ Patrick Henry, "Working in Candide's Garden," Studies in Short Fiction 14, no. 2 (1977), 183.

${ }^{31}$ Speltz, "War and Sentimentalism," 286.

32 Wood, "Notes on Candide," 201.
}

backs on the atrocities they witness during their journey and seclude themselves in an isolated society of their own. But even if it is true that Candide's focus on his own garden turns a blind eye to the rest of the world's issues, Voltaire's message certainly has nothing to do with forgetting. As Wood puts it, Candide is an exercise in "unrelenting memory." ${ }_{33}$ This brings me back to Voltaire's detachment from the characters in his novel. Candide, the character, might be content to turn a blind eye to other people's misery, but Candide, the novel, is a testament to human suffering. Even Candide's humor depends on an acknowledgement of pain. If Voltaire wanted to write a story that endorsed a life of ignorance, he would not have included the grisly detail and forceful satire that characterize Candide. English author Julian Barnes argues in "A Candid View of Candide" that Voltaire intentionally neglects the creation of a meaningful reformation at the end of the novel to deliberately acknowledge that no such reformation exists. Candide is not and should not be taken as an instruction manual for mending the world's atrocities; it is instead "a necessary expression of moral rage." 34

\section{THE SEARCH FOR MEANING}

A deeper analysis of Candide and the events that precede its conclusion can clarify what cultivating one's garden is not. It is not a tribute to pessimism-nor is it a mere endorsement of naiveté. What then does the novel's conclusion recommend we do? Voltaire tempers the caustic, polemic nature of his text with the vague piece of advice that we must cultivate our gardens, knowing that this in no way answers the questions that his work has provoked. In some ways, it might even undermine them. In the end, though Voltaire has assured himself and his readers that idle talk accomplishes nothing, he still recognizes that he cannot answer the question of human suffering. Instead, he proposes an honest lifestyle that might someday produce something better. This is Voltaire's garden. Candide is Voltaire's garden. He plants his ironies and his contradictions in the hope that they may eventually inspire a solution-that in cultivating our own gardens, we might find the answers that he could not.

\section{AUTHOR INFORMATION}

All correspondence should be sent to the first author: sydmadams99@gmail.com.

\section{REFERENCES}

Adams, Robert. "Candide on Work and Candide as Outsider," In Candide, or Optimism: A New Translation, Backgrounds, And Criticism, by Voltaire, translated and edited by Robert Adams. New York: Norton, 1966.

Barnes, Julian. "A Candid View of Candide." The Guardian. Last modified July 1, 2011. Accessed April 14, 2019. http:// www.theguardian.com/books/2011/jul/01/candide-voltairerereading-julian-barnes.

Gay, Peter. Voltaire's Politics: The Poet as the Realist. Princeton: Princeton University Press, 1959.

Henry, Patrick. "Working in Candide's Garden.” Studies in Short Fiction 14, no. 2 (1977): 183-184.

McCarthy, Cormac. The Road. North Essendon: Radiant Heart Publishing, 2014.

\footnotetext{
${ }^{3}$ Ibid

${ }^{34}$ Barnes, "A Candid View of Candide."
} 
Speltz, Andrea. "War and Sentimentalism: Irony in Voltaire's Candide, Sterne's Tristam Shandy, and Lessing's Minna von Barnhelm." Canadian Review of Comparative Literature 44, no. 2 (2017): 282-297.

Voltaire (François-Marie Arouet). Candide and Other Stories. Translated by Roger Pearson. Oxford: Oxford University Press, 1990.

Voltaire (François-Marie Arouet). The Philosophical Dictionary. Translated and edited by Theodore Besterman. New York: Penguin Books, 1972.

Voltaire (François-Marie Arouet). "Poem on the Lisbon Disaster," Toleration and Other Essays. Translated by Joseph McCabe. New York: G. P. Putnam’s Sons, 1912.

Wolper, Roy S. "Candide, Gull in the Garden?" EighteenthCentury Studies 3, no. 2 (1969): 265-277.

Wood, Michael. "Notes on Candide." New England Review 26, no. 4 (2005): 192-202. 